\title{
Determination of Thermal Radiation Emissivity and Absorptivity of Thermal Screens for Greenhouse
}

\author{
Adeel Rafiq ${ }^{1}$, Wook Ho $\mathrm{Na}^{2}$, Adnan Rasheed ${ }^{1}$, Hyeon Tae Kim ${ }^{3}$, and Hyun Woo Lee1,2,4* \\ ${ }^{1}$ Department of Agricultural Engineering, Kyungpook National University, Daegu 41566, Korea \\ ${ }^{2}$ Institute of Agricultural Science and Technology, Kyungpook National University, Daegu 41566, Korea \\ ${ }^{3}$ Dept. of Bio-Industrial Machinery Eng., Gyeongsang National Univ. (Insti. of Agric. \& Life Sci.), Jinju 660-701, Korea \\ ${ }^{4}$ Smart Agriculture Innovation Center, Kyungpook National University, Daegu 41566, Korea
}

\begin{abstract}
Greenhouse farmers often use thermal screens to reduce greenhouse heating expenses during the winter, and for shade during hot, sunny days in the summer, as it is an inexpensive solution to temperature control relative to other available options. However, accurate measurements of their emitted and absorbed radiations are important for the selection of suitable screens that offer maximum performance. Material's ability to save energy is highly dependent on these properties. Limited studies have investigated the measurement of these properties under natural conditions, but they are only applicable to materials having partial porosities. In this work, we describe a new radiation balance method for determining emissive power and absorptive capacity, as well as reflectivity, transmissivity and emissivity of materials having complete and partial transparency by using pyrgeometer and net radiometer. In this study, four materials with zero porosity, were tested. The emissivity value of PE, LD-13, LD-15 and PH-20 was $0.439 \pm 0.020,0.460 \pm 0.010,0.454 \pm 0.004$, and $0.499 \pm 0.006$, respectively. All tested samples showed high emitted radiation as compared to absorbed radiation.
\end{abstract}

Additional key words : image $\mathrm{j}$, net radiometer, pyrgeometer, reflectance

\section{Introduction}

During the colder parts of the year, heating is critical to greenhouse production, as it is essential for achieving the prescribed optimum temperature for crop growth (Sethi et al., 2013; Rasheed et al., 2018b). Thus, when designing a greenhouse, careful selection of appropriate material can positively affect the energy requirements and fuel consumption necessary to maintain optimal growth temperatures (Ponce et al., 2014; Marshall, 2016; Rasheed et al., 2018a)

The effort to support a growing energy demand, while simultaneously reducing fossil fuel impacts on the environment, has motivated the scientific community to invest significant time, money, and resources into extensively investigating the application of renewable energy (Adaramola, 2012). As part of that effort, numerous studies have focused on alternative ways to achieve greenhouse heating (Pucar, 2002; Kürklü and Bilgin, 2004; Ghosal and Tiwari, 2006; Abdel-Ghany and Al-Helal, 2011; Joudi and Farhan,

*Corresponding author: whlee@knu.ac.kr

Received June 30, 2019; Revised August 20, 2019;

Accepted August 22, 2019
2014). The aim of these studies was minimize greenhouse energy intake by using alternative approaches, such as: increasing shortwave radiation availability inside the greenhouse, reducing energy loss to the outside environment, and increasing the greenhouse's constituent storage ability.

Thermal screens are commonly used in greenhouses to minimize heat loss at night during the winter and to provide adequate shading during the summer (Shukla et al., 2008). Accurate measurement of the screen's longwave radiometric properties are important for selecting an appropriate screen to maintain optimal environmental conditions for plants during the night (Rafiq et al., 2019). These properties can be input into a physical model and used to calculate the amount of saved energy for different screens, thereby permitting a performance comparison between the different screen options.

Spectrophotometers, infrared sensors, and many other instruments are appropriate and available for measuring the properties of simple materials. However, the screen's perforated nature and compositional complexity makes it impractical to use these instruments for accurately measuring the absorbed and emitted radiation (Abdel-Ghany et al., 2015a). To date, no standard technique is available for 
measuring the screens' long-wave properties that can be applied to a diverse array of material types.

This study describes an experimental procedure for determining absorptive and emissive power along with reflectivity, transmissivity and emissivity of energy-saving greenhouse screens. Our method uses simple radiation balance equations and inexpensive radiometers in contrast to complicated procedures and costly scientific equipment. The results of our calculations allow researchers and growers alike to determine whether a material is a good heat insulator or conductor under natural environmental conditions. Such information permits comparison of energy performance between different screens and equips growers with necessary information to make an informed investment choice.

\section{Materials and Methods}

\section{Material properties and composition}

To carry out this experiment, four symmetric materials (identical on both sides) of the same category but with different compositions were selected and tested. The tested materials' properties and nature are presented in Table 1. PhormiTex PHL 20 (PH-20) is an energy saving gable screen. Luxous-1547 D FR (LD-15) combines good heat retaining properties with high light diffusion and transmission. The diffusion brings light to the plants from various directions, reducing overheating of upper areas. The main function of Luxous-1347 D FR (LD-13) is saving energy through maximum light transmission. Polyethylene(PE) is primarily plastic film that is preferred by most

Table 1. Properties of the tested materials

\begin{tabular}{|c|c|c|c|c|c|}
\hline Properties & $\begin{array}{l}\text { Weight } \\
\left(\mathrm{g} / \mathrm{m}^{2}\right)\end{array}$ & $\begin{array}{l}\text { Thickness } \\
(\mathrm{mm})\end{array}$ & $\begin{array}{l}\text { Width of strips } \\
\qquad(\mathrm{mm})\end{array}$ & Composition & $\begin{array}{c}\text { Transparency } \\
(\%)\end{array}$ \\
\hline PH-20 & 108 & 0.27 & 4 & $100 \%$ Polyethylene & 80 \\
\hline LD-13 & 58 & 0.22 & 4 & $100 \%$ Polyester & 75 \\
\hline LD-15 & 51 & 0.18 & 4 & $100 \%$ Polyester & 75 \\
\hline $\mathrm{PE}$ & 84 & 0.07 & - & 100\% Polyethylene & 100 \\
\hline
\end{tabular}
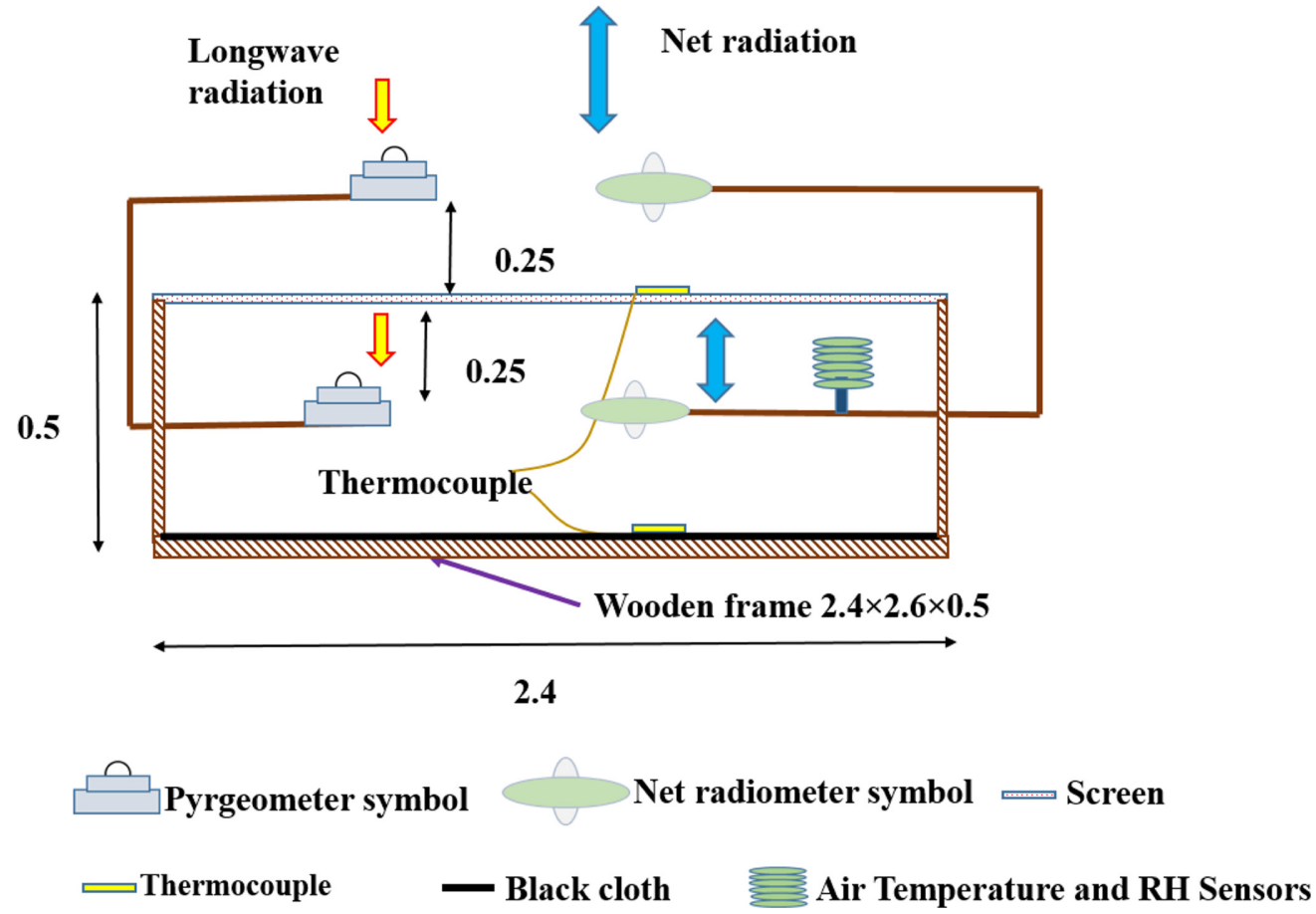

Fig. 1. Illustration of the experimental structure, units in [m], not to scale. 
Table 2. List of equipment and data loggers

\begin{tabular}{|c|c|c|c|c|}
\hline Parameter & Unit & Sensors & Range & Data logger \\
\hline Net long-wave radiation & $\mathrm{W} / \mathrm{m}^{2}$ & $\begin{array}{l}\text { NR Lite2 Net Radiometer } \\
\text { (Kipp and Zonen, Netherlands) }\end{array}$ & $0.2-100 \mu \mathrm{m}$ & $\begin{array}{c}\text { LR } 5041 \\
\text { (Hioki, Japan) }\end{array}$ \\
\hline Downward long-wave radiation $(\mathrm{La})$ & $\mathrm{W} / \mathrm{m}^{2}$ & $\begin{array}{c}\text { CGR3 Pyrgeometer } \\
\text { (Kipp and Zonen, Netherlands) }\end{array}$ & $4.5-42 \mu \mathrm{m}$ & $\begin{array}{c}\text { 21x Micrologger } \\
\text { (Campbell Scientific, Inc. USA) }\end{array}$ \\
\hline Downward long-wave radiation (Lc) & $\mathrm{W} / \mathrm{m}^{2}$ & $\begin{array}{c}\text { IR02 Pyrgeometer } \\
\text { (Hukseflux, Netherlands) }\end{array}$ & $4.5-40 \mu \mathrm{m}$ & $\begin{array}{c}\text { CR300 } \\
\text { (Campbell Scientific, Inc. USA) }\end{array}$ \\
\hline Temperature/Relative Humidity & ${ }^{\circ} \mathrm{C} / \%$ & $\begin{array}{l}\text { Hobo pro v2 U23-002 } \\
\text { (Onset, USA) }\end{array}$ & $\begin{array}{c}-40{ }^{\circ} \mathrm{C}-70{ }^{\circ} \mathrm{C} \\
0 \%-100 \%\end{array}$ & $\begin{array}{l}\text { Hobo pro v2 U23-002 } \\
\text { (Onset, USA) }\end{array}$ \\
\hline Surface temperature & ${ }^{\circ} \mathrm{C}$ & T-type thermocouple wires & $-270{ }^{\circ} \mathrm{C}-370^{\circ} \mathrm{C}$ & $\begin{array}{l}\text { Hobo UX120-014M } \\
\text { (Onset, USA) }\end{array}$ \\
\hline
\end{tabular}

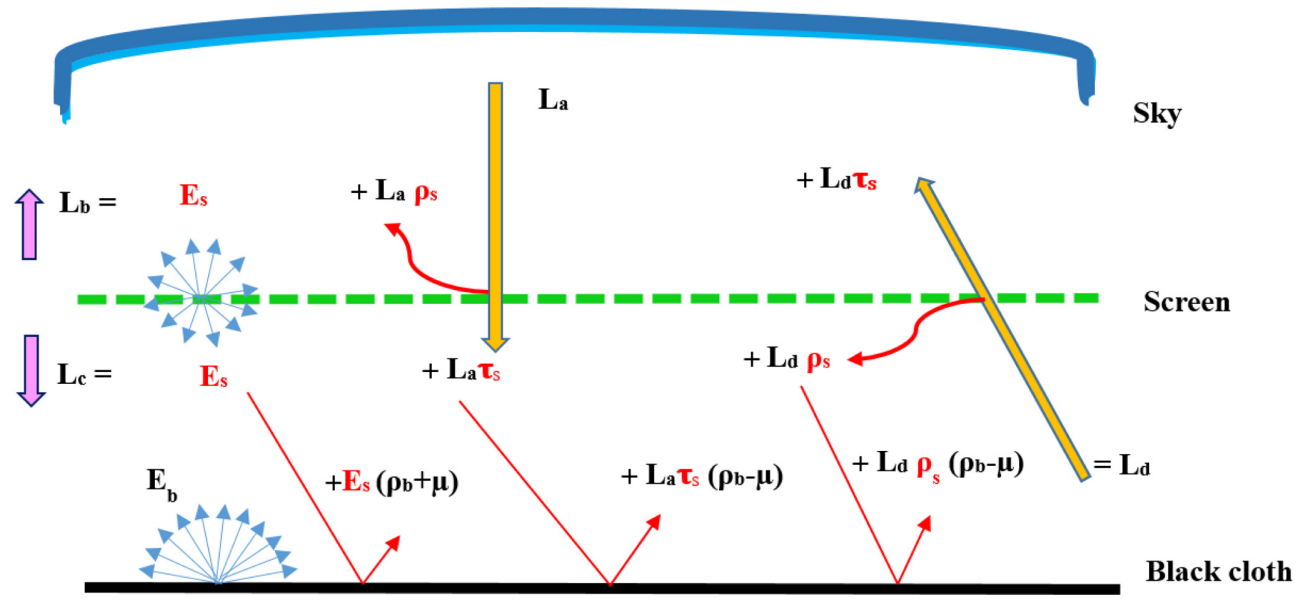

Fig. 2. Ideal drawing of the inward $\left(\mathrm{L}_{\mathrm{a}}\right.$ and $\left.\mathrm{L}_{\mathrm{d}}\right)$ and the outward $\left(\mathrm{L}_{\mathrm{b}}\right.$ and $\left.\mathrm{L}_{\mathrm{c}}\right)$ radiations from the screen.

agricultural growers due to its affordability, flexibility, and easy manufacturing. In this study, polyethylene was used as a standard reference material due to its well-known properties, which are widely reported in the literature. The material, which is transparent and partially porous, was tested to confirm the accuracy of results obtained by our proposed method.

\section{Experimental setup}

This experiment was conducted on a building roof in order to obtain clear sky radiations. A hollow wooden frame was built, the bottom of which was covered with a black cloth of known radiometric properties $\left(\tau_{\mathrm{b}}=0\right.$, $\left.\rho_{\mathrm{b}}=0.07, \varepsilon_{\mathrm{b}}=0.93\right)$. The frame measurements were $2.4 \mathrm{~W}$ $\times 2.6 \mathrm{~L} \times 0.5 \mathrm{H} \mathrm{m}$, and the $3 \mathrm{D}$ structure enclosed by the frame had a total volume of $3.12 \mathrm{~m}^{3}$. Fig. 1 depicts the frame dimensions and the equipment positions. One night is required to examine one sample screen and each material was tested from 18:00 to 6:00 o'clock. Downward longwave radiation $\left(\mathrm{L}_{\mathrm{a}} \& \mathrm{~L}_{\mathrm{c}}\right)$ was measured with a pyrgeometer, while upward fluxes $\left(\mathrm{L}_{b} \& \mathrm{~L}_{d}\right)$ were computed from the difference between net radiometer and the downward fluxes. Two thermocouple wires, with a very thin diameter, were used to measure the black cloth's surface temperature. All measured parameters were recorded at 10minute intervals and saved in each parameter's corresponding data logger. Table 2 depicts the list of employed equipment and data loggers.

\section{Theory}

The outgoing long-wave radiation equation above the screen surface $\left(\mathrm{L}_{\mathrm{b}}\right)$ for symmetric materials is given below, where $\mathrm{L}_{\mathrm{b}}$ is in $\mathrm{W} / \mathrm{m}^{2}$.

$$
\begin{aligned}
& \mathrm{L}_{\mathrm{b}}=\mathrm{E}_{\mathrm{s}}+\rho_{\mathrm{s}} \mathrm{L}_{\mathrm{a}}+\tau_{\mathrm{s}} \mathrm{L}_{\mathrm{d}} \\
& \mathrm{L}_{\mathrm{c}}=\mathrm{E}_{\mathrm{s}}+\tau_{\mathrm{s}} \mathrm{L}_{\mathrm{a}}+\rho_{\mathrm{s}} \mathrm{L}_{\mathrm{d}}
\end{aligned}
$$


where $\rho_{\mathrm{s}}$ is the screen reflectance, $E_{\mathrm{s}}$ is the screen's emissive power in $\mathrm{W} / \mathrm{m}^{2}, \tau_{\mathrm{s}}$ is the screen's transmittance, and $\mathrm{L}_{\mathrm{a}}$ is the downward sky radiation in $\mathrm{W} / \mathrm{m}^{2}$.

The outgoing long-wave radiation equation over the black surface $\left(\mathrm{L}_{\mathrm{c}}\right)$ and below the screen surface for symmetric materials is given below, where $\mathrm{L}_{\mathrm{c}}$ is in $\mathrm{W} / \mathrm{m}^{2}$.

The reflected portion of incoming long-wave radiation toward the screen, above the black cloth $\left(\mathrm{L}_{\mathrm{d}}\right)$, depends upon the screen's physical condition. The incoming radiation $\left(\mathrm{L}_{\mathrm{d}}\right)$ of transparent and semitransparent materials or materials with partial porosities is given below, where $L_{d}$ is in $\mathrm{W} / \mathrm{m}^{2}$.

$$
L_{d}=E_{b}+\left(\rho_{b}+\mu\right) E_{s}+\left(\rho_{b}-\mu\right) \rho_{s} L_{d}+\left(\rho_{b}-\mu\right) \tau_{s} L_{a}
$$

Where $\rho_{b}$ is the black cloth's reflectance. $E_{b}$ is the black cloth's emissive power in $\mathrm{W} / \mathrm{m}^{2}$, which was determined by Stefan-Boltzmann's law. The emissive power of black can also be calculated using the following equations:

$$
\begin{aligned}
& \mathrm{E}_{\mathrm{b}}=\left(\mathrm{L}_{\mathrm{d}}-\mathrm{L}_{\mathrm{c}} * \rho_{\mathrm{b}}\right) \\
& \mathrm{E}_{\mathrm{b}}=\left(\mathrm{L}_{\mathrm{d}} * \varepsilon_{\mathrm{b}}\right)
\end{aligned}
$$

In the aforementioned equation (3), reflection of all three components $\left(E_{s}, \rho_{s} L_{d}\right.$, and $\left.\tau_{s} L_{a}\right)$ from the black cloth's surface are considered because $\tau_{\mathrm{s}} \mathrm{L}_{\mathrm{a}}$ will reach the black cloth's surface, either from porosity or the presence of transparent material in the sample's composition; and $\rho_{s} L_{d}$ will reach the black cloth's surface due to the presence of opaque material, e.g., thread. Using the iteration method in Matlab to simultaneously solve the three equations $(1,2$ and 3) results in equation (3) causing compatibility issues, even though the number of equations equals the number of unknowns. In order to make these equations compatible to solve simultaneously, micro $(\mu)=10^{\wedge-6}$, is subtracted from the reflected portion of $\tau_{\mathrm{s}} \mathrm{L}_{\mathrm{a}}$ and $\rho_{\mathrm{s}} \mathrm{L}_{\mathrm{d}}$, and added into the reflected portion of $E_{s}$ in equation (3). $\mu$ is the smallest assumed number that can act as tolerance for the black cloth's reflectance $\left(\rho_{\mathrm{b}}\right)$. It has no significant effect on the value, but it helps to circumvent the equations' compatibility issue. Subtraction and addition is based on the radiation strength.

The multiple reflections (i.e., $\rho_{\mathrm{s}}{ }^{2}, \rho_{\mathrm{s}}{ }^{3}$ and $\rho_{\mathrm{b}}{ }^{2}, \rho_{\mathrm{b}}{ }^{3}$ ) of thermal radiation between the screen and the black cloth were ignored. No angular interaction between the sample materi- als and the incident radiation was considered. The absorbed longwave radiation by screen $\left(\mathrm{A}_{\mathrm{s}}\right)$ can be calculated as:

$$
\mathrm{A}_{\mathrm{s}}=\alpha_{\mathrm{s}} *\left(\mathrm{~L}_{\mathrm{a}}+\mathrm{L}_{\mathrm{d}}\right)
$$

Where $\alpha_{\mathrm{s}}$ is the screen's absorption.

\section{Transparency measurement}

Transparency is defined as the ratio between the nonopaque portion and the total area of a sample's materials. Its measurement is important because it can aid in selecting a suitable pair of equations for the radiative properties' measurement. In this study, the image processing method was used, as it is both fast and accurate. ImageJ software was employed for processing the images, which is a freely accessible source Java image processing program inspired by NIH Image that can compute the area and pixel value statistics of user-defined selections. Furthermore, it can measure distances and angles. For image processing, the first screens were tacked to a small frame $(4 \mathrm{~cm} \times 4 \mathrm{~cm})$ and scanned at 300 dpi resolution with a flatbed scanner (Scanjet 5550c, HP, USA). Scanned images were then converted to black-and-white images by changing the image type to 8-bit and using a bandpass filter. Set scale command was used to adjust the image scale. These steps are essential for real and accurate measurement of the area. Final steps included thresholding and particle analysis of non-opaque areas in the images. After the measurement of empty area, an excel sheet was used to estimate the final value of the materials' transparency.

\section{Results and Discussion}

This experiment was conducted under dry and clear sky conditions. Environmental parameters - i.e., air temperature and relative humidity - were also recorded, as previous studies (Cohen and Fuchs, 1999; Abdel-Ghany and AlHelal, 2012) reported the effect of these parameters on experimental results. Temperature of surrounding air of sample materials was shown in Fig. 3. Highest difference between maximum and minimum value of temperature was recorded for LD-15 and PE which was more than $8^{\circ} \mathrm{C}$. Lowest temperature variation was recorded for LD-13 which was about $6.2^{\circ} \mathrm{C}$. Fig. 4 clearly depicts that relative humidity gradually increases as night progresses. Even though air temperature and relative humidity varied significantly but these 
Determination of Thermal Radiation Emissivity and Absorptivity of Thermal Screens for Greenhouse

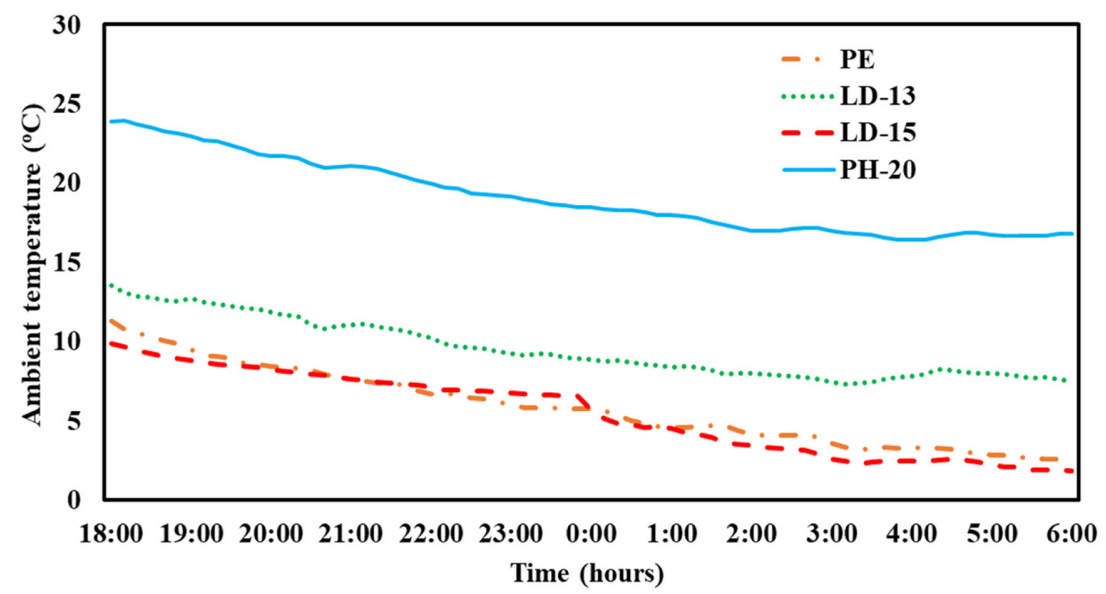

Fig. 3. Air temperature logged during the analysis for all materials.

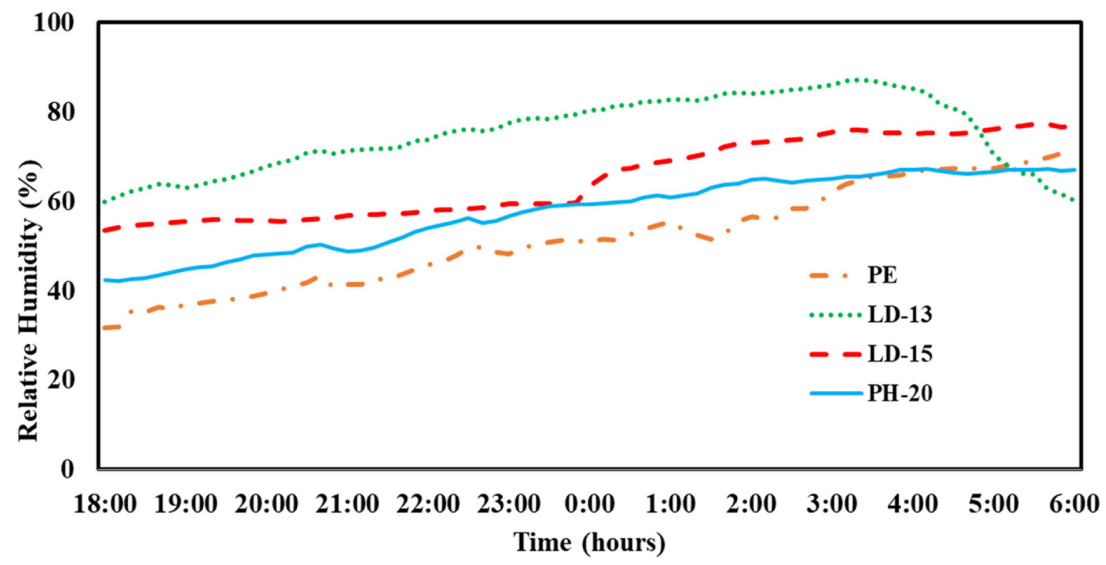

Fig. 4. Relative humidity logged during the analysis for all materials.

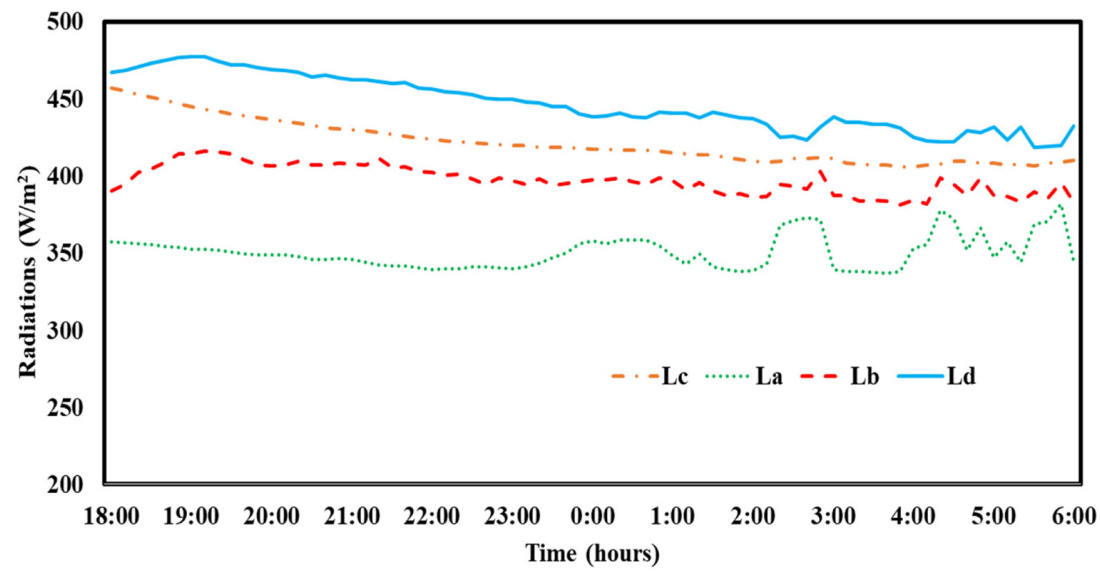

Fig. 5. Inward ( $L_{a}$ and $\left.L_{d}\right)$ and outward $\left(L_{b}\right.$ and $\left.L_{c}\right)$ radiations for PH-20.

factors showed no impact on the properties.

Fig. 5 demonstrates the incoming and outgoing radiations of PH-20. Downward radiations were directly mea- sured by a pyrgeometer and upward radiations were calculated using a procedure reported in (Blonquist $\mathrm{Jr}$ et al., 2009). 
Adeel Rafiq, Wook Ho Na, Adnan Rasheed, Hyeon Tae Kim, and Hyun Woo Lee

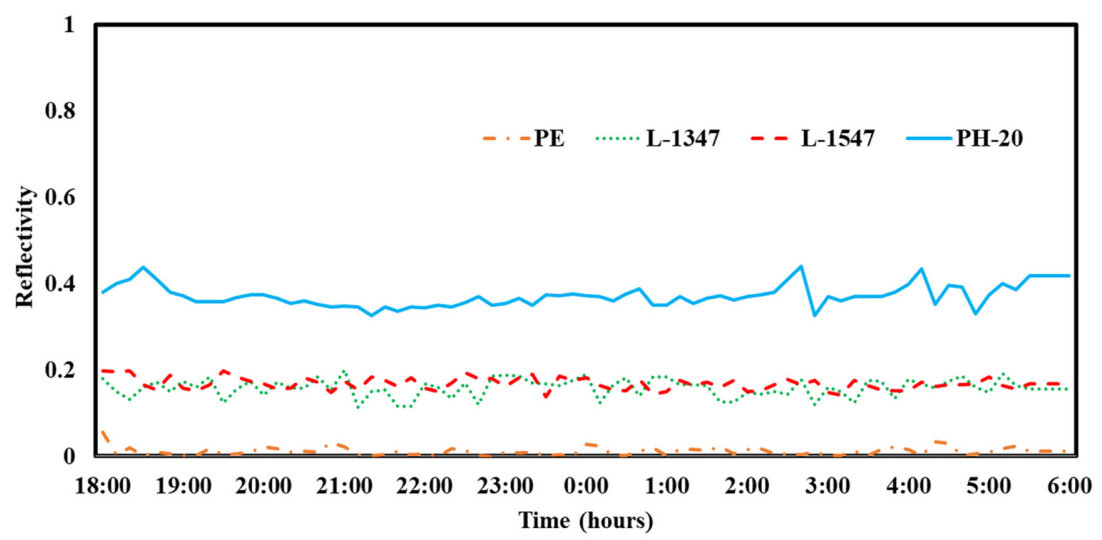

Fig. 6. Reflectivity of all tested materials.

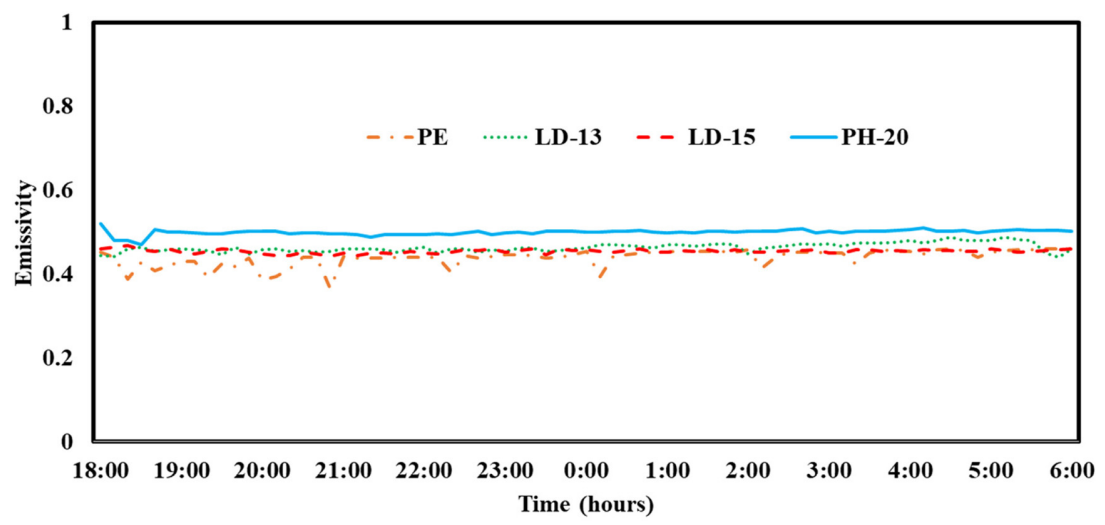

Fig. 7. Emissivity of all tested materials.

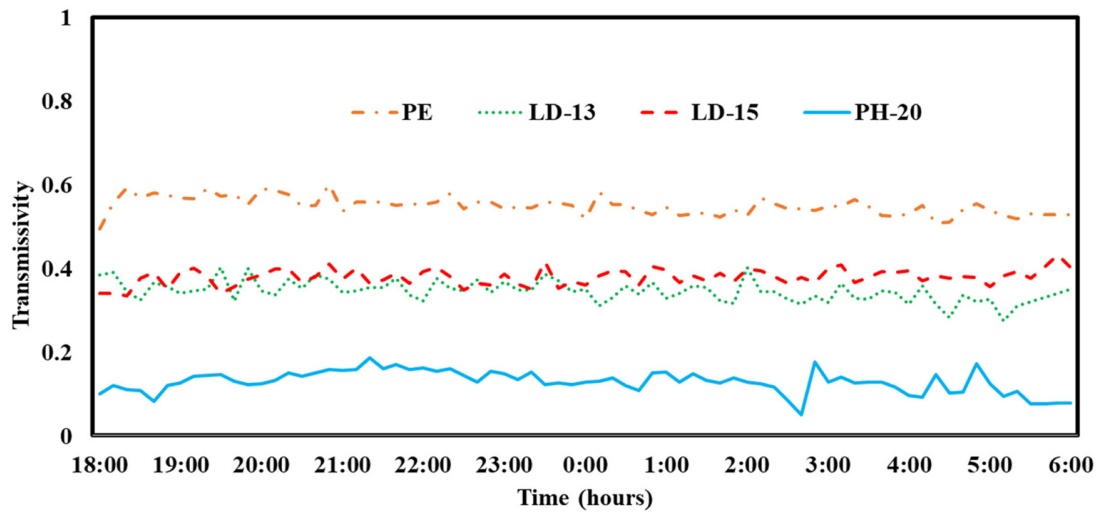

Fig. 8. Transmissivity of all tested materials.

Comparison of the tested samples' reflectivity, emissivity, and transmissivity are presented in Figs. 6-8, respectively. PH-20 showed a high reflectance as compared to the other materials. Such materials can reduce temperatures by $1-7^{\circ} \mathrm{C}$, as reported by (Hernández-Pérez et al., 2014). PE results are in good agreement with the values reported by (Gentle et al., 2013). LD-13 and LD-15 have the same structure, but they differ in that LD-13 has shiny surface. Interestingly, both materials exhibited very similar longwave radiative properties - value differences did not exceed 
Determination of Thermal Radiation Emissivity and Absorptivity of Thermal Screens for Greenhouse

Table 3. Average values of radiometric properties

\begin{tabular}{cccccccc}
\hline \hline Measuring date & $\begin{array}{c}\text { Sample } \\
\text { material }\end{array}$ & $\begin{array}{c}\text { Average } \\
\text { emissivity }\end{array}$ & S.D. & $\begin{array}{c}\text { Average } \\
\text { transmissivity }\end{array}$ & S.D. & $\begin{array}{c}\text { Average } \\
\text { reflectivity }\end{array}$ & S.D. \\
\hline 20-21 Nov-2018 & PE & 0.439 & 0.020 & 0.549 & 0.021 & 0.168 & 0.009 \\
27-28 Nov-2018 & LD-13 & 0.460 & 0.010 & 0.382 & 0.034 & 0.158 & 0.021 \\
23-24 Feb-2019 & LD-15 & 0.454 & 0.004 & 0.378 & 0.019 & 0.168 & 0.014 \\
20-21 April-2019 & PH-20 & 0.499 & 0.006 & 0.129 & 0.025 & 0.372 & 0.025 \\
\hline
\end{tabular}

S.D. $=$ Standard deviation

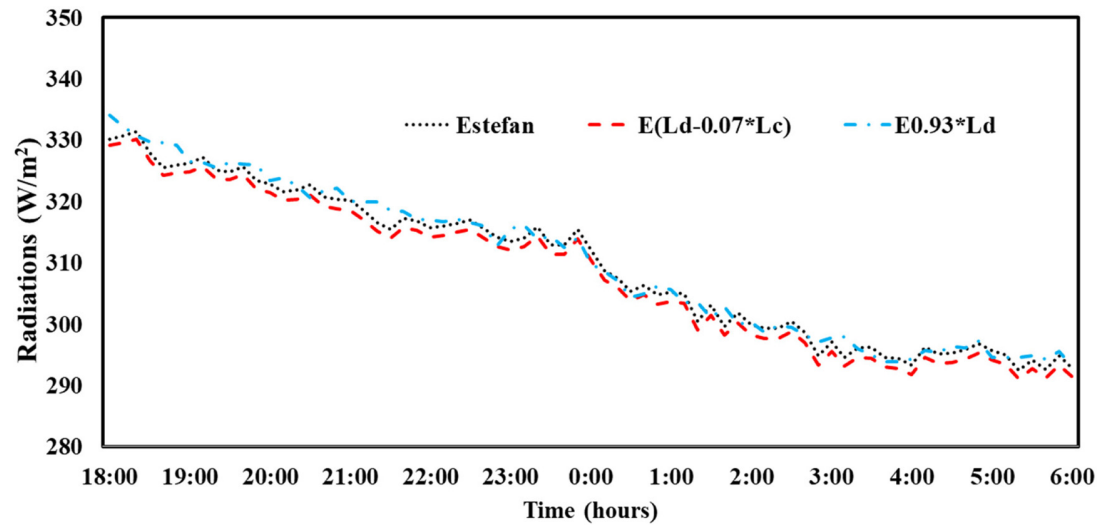

Fig. 9. Emissive power of black cloth during the analysis of LD-15.

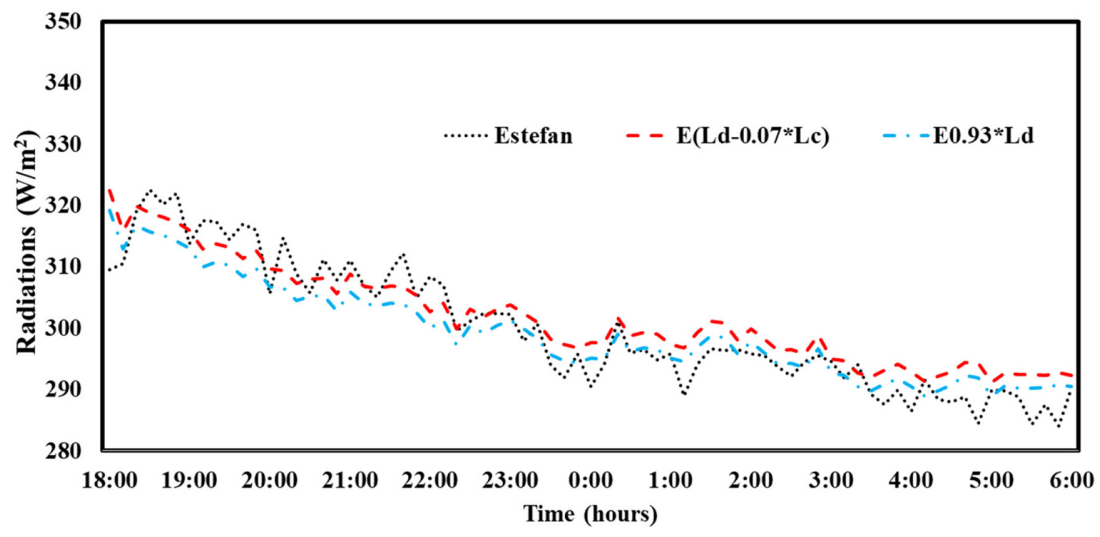

Fig. 10. Emissive power of black cloth during the analysis of $\mathrm{PE}$

$2-3 \%$ - even though the surfaces had different lusters. All the materials displayed similar emissivity values, except PH-20, which showed 5-6\% more emittance than the other materials. Further, the comparison of the average values of radiometric properties with standard deviation is shown in Table 3.

Emitted radiation of any material is usually measured with the Stefan Boltzmann equation, but in this experiment, the black cloth's emissive power was measured via three methods. First method is based on the famous Stefan
Boltzmann equation, which requires surface temperature and emissivity values. The other two methods are specially designed, based on a similar setup to what was used in this study. The second method's output is simply acquired by multiplying incoming radiations $\left(\mathrm{L}_{\mathrm{d}}\right)$ with 0.93 ; and the last method is based on radiation balance equation (4). Figs. 910 illustrate the black cloth's emissive power for two tested sample screens. Note that the values obtained using newly described methods are very close to the actual measurement by the Stefan Boltzmann equation. 
Adeel Rafiq, Wook Ho Na, Adnan Rasheed, Hyeon Tae Kim, and Hyun Woo Lee

Figs. 11-14 present the absorbed and emitted radiation results from the tested sample materials. These figures clearly show that emitted radiation (2E) was always greater than absorbed radiation for all the materials. Similar findings were reported by Abdel-Ghany et al., 2015b, despite the fact that they used different materials and different cal-

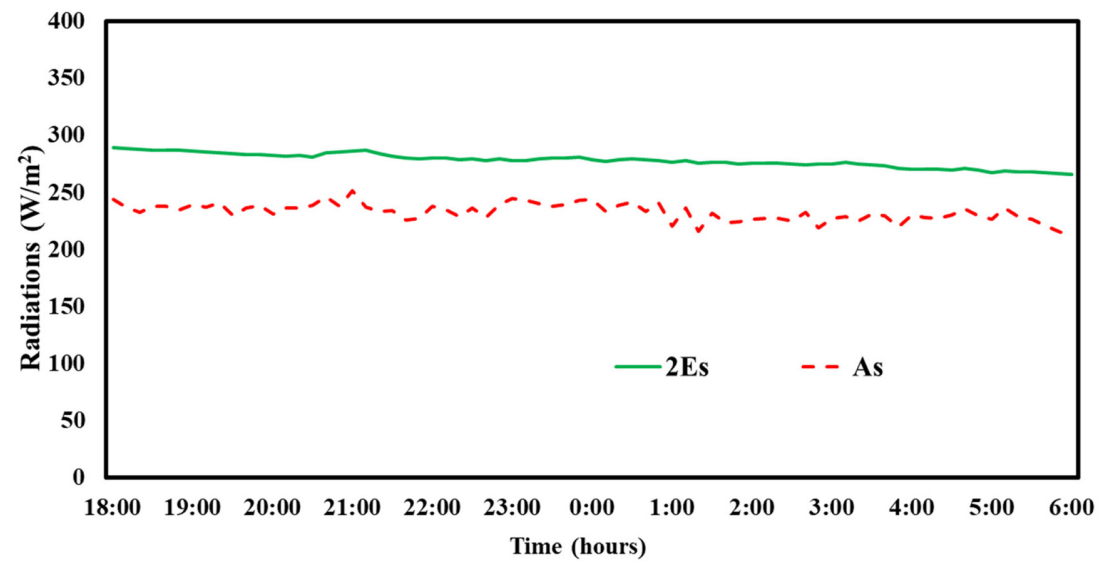

Fig. 11. Absorbed and emitted radiations by LD-13.

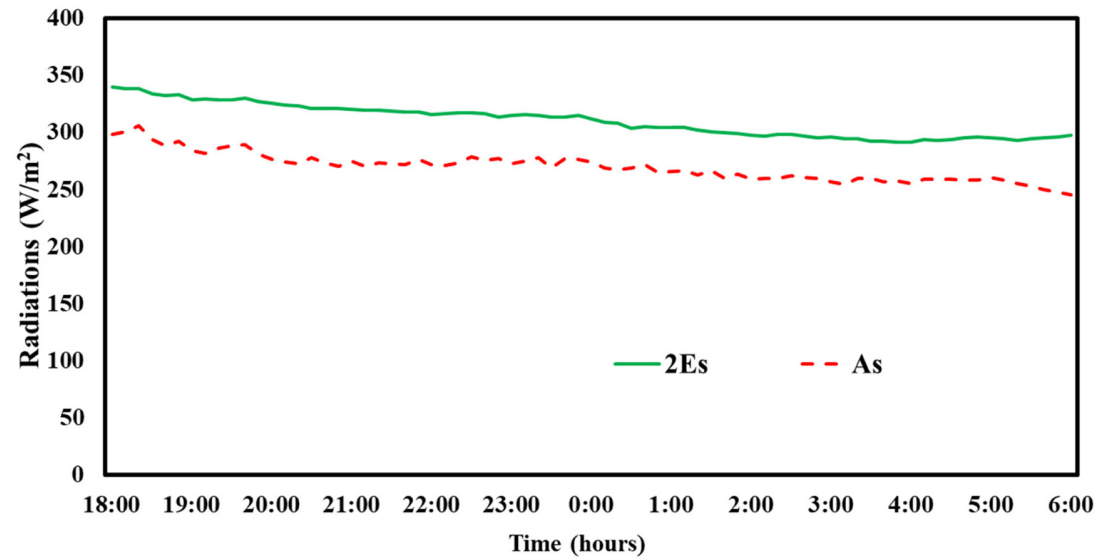

Fig. 12. Absorbed and emitted radiations by LD-15.

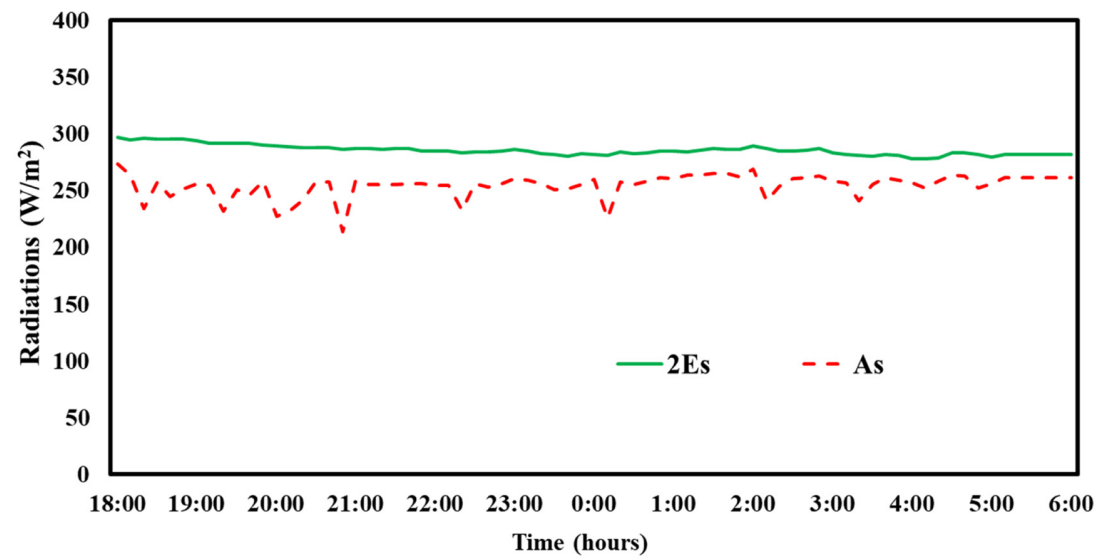

Fig. 13. Absorbed and emitted radiations by PE. 


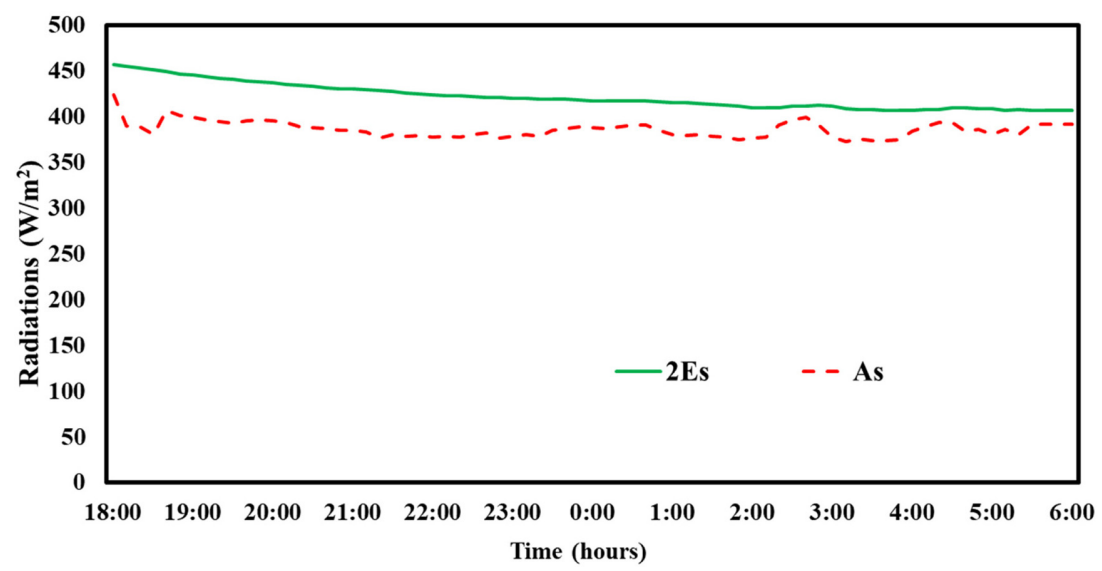

Fig. 14. Absorbed and emitted radiations by PH-20.

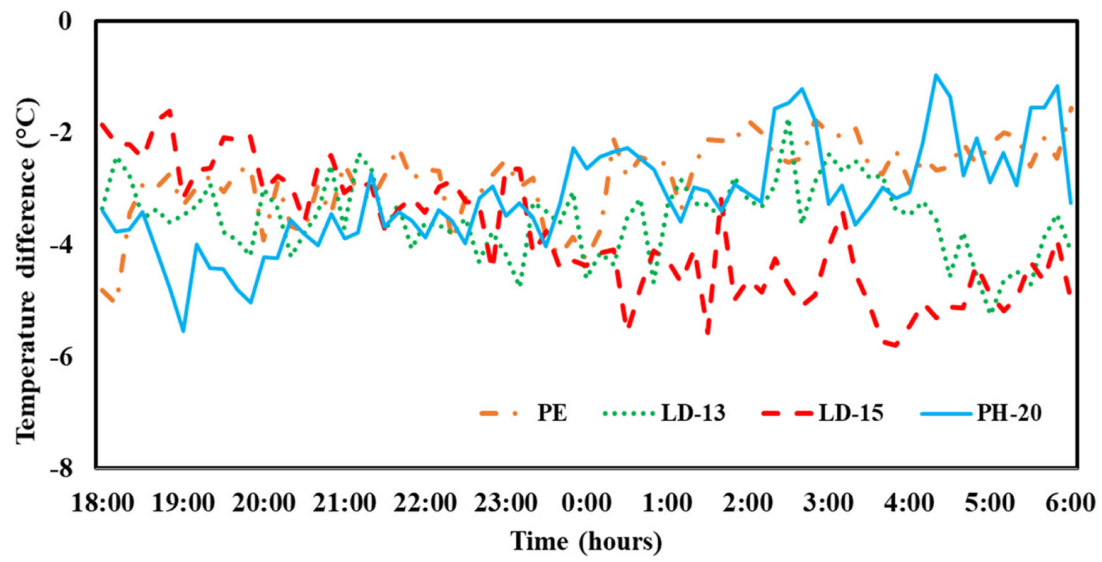

Fig. 15. Difference between ambient and screen temperature calculated for each sample.

culation methodology. Emitted radiation primarily depends on the material's absolute temperature and emissivity. Sample materials were also exposed to sunlight for an entire day, prior to the actual experiment start time. This received energy would be released from the materials during the night, as longwave radiation. In contrast, absorbed radiation predominantly relies on sky radiation $\left(\mathrm{L}_{\mathrm{a}}\right)$, radiation coming from black cloth $\left(\mathrm{L}_{\mathrm{d}}\right)$, and absorptivity and angle of incident radiation. Another factor in this setup that can add or subtract energy to/from the material is convective exchange. In order to clarify the effect of energy exchange between the air and materials, the temperature difference was measured and recoded. Results are shown in Fig. 15. This diagram demonstrates that ambient temperature was always higher than the screen materials' surface temperature. Higher screen and film temperature is clear evidence of energy flow from air to materials.

\section{Conclusion}

Experiment was conducted during night time to investigate the material's potential to conserve energy. Radiation balance method was applied in order to get the absorptive and emissive power along with reflectivity, transmissivity and emissivity of energy-saving greenhouse screens by using wide band radiometer. The ability of materials to save energy is dependent on these properties. Based on the results we concluded that $\mathrm{PH}-20$ has greater potential to conserve as it has high reflectance and better absorptive power as compared to other sample materials. Other three tested materials have same potential to absorb energy. LD13 and LD-15 showed similar properties so they can save energy with equal capacity but less than that of PH-20. The result of PE showed results opposite to PH-20 as it exhibited nearly zero reflectance and high transmission value. 
Surly, PE will radiate more energy due to high transmissivity among the tested materials.

\section{Acknowledgements}

This work was supported by the Korea Institute of Planning and Evaluation for Technology in Food, Agriculture, Forestry and Fisheries (IPET) through Agriculture, Food and Rural Affairs Research Center Support Program, funded by Ministry of Agriculture, Food and Rural Affairs (MAFRA) (717001-7). This research was supported by Kyungpook National University Development Project Research Fund, 2018.

\section{Symbolization}

$\mathrm{L}_{\mathrm{b}}=$ Outgoing long-wave radiation above the screen surface in $\mathrm{W} / \mathrm{m}^{2}$

$\mathrm{L}_{\mathrm{c}}=$ Outgoing long-wave radiation over the black surface in $\mathrm{W} / \mathrm{m}^{2}$

$\mathrm{L}_{\mathrm{d}}=$ Incoming long-wave radiation toward the screen above the black cloth in $\mathrm{W} / \mathrm{m}^{2}$

$\mathrm{E}_{\mathrm{b}}=$ Emissive power of the black cloth in $\mathrm{W} / \mathrm{m}^{2}$

$E_{\mathrm{s}}=$ Emissive power of the screen in $\mathrm{W} / \mathrm{m}^{2}$

$\tau_{\mathrm{s}}=$ Transmittance of the screen

$\rho_{\mathrm{s}}=$ Reflectance of the screen

$\varepsilon_{\mathrm{s}}=$ Emittance of the screen

$\rho_{\mathrm{b}}=$ Reflectance of the black cloth

$\mathrm{PE}=$ Polyethylene

\section{Literature Cited}

Abdel-Ghany, A.M., and I. M. Al-Helal. 2011. Solar energy utilization by a greenhouse:general relations. Renew Energy. 36(1):189-196.

Abdel-Ghany, A. M., and I. M. Al-Helal. 2012. A method for determining the long-wave radiative properties of a plastic shading net under natural conditions. Sol Energy Mat Sol C. 99:268-276.

Abdel-Ghany, A.M., I. M. Al-Helal, M. Shady, and A. Ibrahim. 2015b. Convective heat transfer coefficients between horizontal plastic shading nets and air. Energ. Buildings. 93:119-125.

Abdel-Ghany, A.M., I. M. Al-Helal, and M. R. Shady. 2015a. On the emissivity and absorptivity of plastic shading nets under natural conditions. Adv Mech Eng. 7:1-9.

Adaramola, M. S. 2012. Estimating global solar radiation using common meteorological data in akure, nigeria. Renew Energy. 47:38-44.
Blonquist Jr, J., B. Tanner, and B. Bugbee. 2009. Evaluation of measurement accuracy and comparison of two new and three traditional net radiometers. Agric. For. Meteorol. 149(10):1709-1721.

Cohen, S., and M. Fuchs. 1999. Measuring and predicting radiometric properties of reflective shade nets and thermal screens. J Agr Eng Res. 73(3):245-255.

Gentle, A., K. Dybdal, and G. Smith. 2013. Polymeric mesh for durable infra-red transparent convection shields:applications in cool roofs and sky cooling. Sol Energy Mat Sol C. 115:79-85.

Ghosal, M., and G. Tiwari. 2006. Modeling and parametric studies for thermal performance of an earth to air heat exchanger integrated with a greenhouse. Energ Convers Manag. 47(13-14):1779-1798.

Hernández-Pérez, I., G. Álvarez, J. Xamán, I. Zavala-Guillén, J. Arce, and E. Simá. 2014. Thermal performance of reflective materials applied to exterior building components-a review. Energ. Buildings. 80:81-105.

Joudi, K. A., and A. A. Farhan. 2014. Greenhouse heating by solar air heaters on the roof. Renew Energy. 72:406-414.

Kürklü, A., and S. Bilgin. 2004. Cooling of a polyethylene tunnel type greenhouse by means of a rock bed. Renew Energy. 29(13):2077-2086.

Marshall, R. 2016. How to build your own greenhouse:designs and plans to meet your growing needs. Storey Publishing. North Adams,USA.

Ponce, P., A. Molina, P. Cepeda, E. Lugo, and B. MacCleery. 2014. Greenhouse design and control. CRC Press.Boca Raton,USA.

Pucar, M. D. 2002. Enhancement of ground radiation in greenhouses by reflection of direct sunlight. Renew Energy. 26(4):561-586.

Rafiq, A., W. H. Na, A. Rasheed, and H. W. Lee. 2019. Measurement of long-wave radiative properties of energy-saving greenhouse screens. Pak J Agr Sci (Submitted in May).

Rasheed, A., J. W. Lee, and H. W. Lee. 2018a. Development and optimization of a building energy simulation model to study the effect of greenhouse design parameters. Energies. 11(8):1-19.

Rasheed, A., J. W. Lee, and H. W. Lee. 2018b. Evaluation of overall heat transfer coefficient of different greenhouse thermal screens using building energy simulation. Protected Hort. Plant Fac. 27(4):294-301.

Sethi, V., K. Sumathy, C. Lee, and D. Pal. 2013. Thermal modeling aspects of solar greenhouse microclimate control:a review on heating technologies. Solar energy. 96:5682.

Shukla, A., G. Tiwari, and M. Sodha. 2008. Experimental study of effect of an inner thermal curtain in evaporative cooling system of a cascade greenhouse. Solar energy. 82(1):61-72. 


\section{온실 스크린의 장파복사 방사율 및 흡수율 결정 \\ 라피크아딜 ${ }^{1} \cdot$ 나욱호 $^{2}$ · 라쉬드아드난 ${ }^{1} \cdot$ 김현태 $^{3} \cdot$ 이현우 $^{1,2,4 *}$ \\ 1경북대학교 농업토목공학과, ${ }^{2}$ 경북대학교 농업과학기술연구소, 3경상대학교 생물산업기계공학과, ${ }^{4}$ 경북대학교 스마트농업혁신센터}

적 요. 온실에서 겨울철 야간에는 열손실을 줄이기 위한 목적으로, 여름철 주간에는 차광을 위한 목적으로 스 크린을 사용하고 있다. 온실의 냉난방 에너지 절감효과에 큰 영향을 미치는 스크린의 장파복사 방사율과 흡수 율은 온실에 설치할 적절한 스크린을 선택하는데 있어서 중요한 요소가 되며 이러한 특성값들을 정확하게 측 정할 수 있는 방법이 필요하다. 외부 환경조건에서 스크린의 장파복사 특성의 측정과 관련된 연구가 일부 수 행된 바 있지만 모든 종류의 스크린에 적용할 수 있는 방법은 아니고 공극이 있는 스크린 자재에만 적용이 가 능한 방법이다. 본 연구에서는 순복사계 및 야간복사계를 사용하여 온실 스크린의 장파복사 흡수량과 방사량을 측정하고, 방사율, 흡수율 및 투과율을 결정하는 새로운 방법을 제시하였다. 특성값의 측정은 공극이 0 인 4 가 지 종류의 스크린 자재에 대하여 수행하였다. 모든 자재가 장파복사 방사량이 흡수량보다 높게 나타났다. $\mathrm{PE}$, LD-13, LD-15 and PH-2의 장파복사 방사율은 각각 $0.439 \pm 0.020,0.460 \pm 0.010,0.454 \pm 0.004$, and $0.499 \pm 0.006$ 범위로 나타났다.

추가주제어: 반사율, 순복사계, 야간복사계, 이미지J 